DOI: https://doi.org/10.34069/AI/2021.42.06.15

How to Cite:

Nkpoyen, F., Archibong, E.P., Undelikwo, V., Obeten, U.B., \& Ofem, N.O. (2021). Social welfare program and poverty eradication in sub-saharan region of Eket Senatorial district, Akwa Ibom State, Nigeria. Amazonia Investiga, 10(42), 163-175. https://doi.org/10.34069/AI/2021.42.06.15

\title{
Social welfare program and poverty eradication in sub-saharan region of Eket Senatorial district, Akwa Ibom State, Nigeria
}

\section{Programa de bienestar social y erradicación de la pobreza en la región subsahariana del distrito Senatorial de Eket, Estado de Akwa Ibom, Nigeria}

Received: April 4, 2021

\section{Abstract}

The study investigated development gap in social policy and social problem interaction by examining impact of National Poverty Eradication Programme (NAPEP) on rural communities in Akwa Ibom State, Nigeria. The specific objectives were to examine the relationship between non-participation of beneficiary communities in NAPEP project design at community level, corruption and policy implementation strategy on rural poverty reduction. The Ex-post facto research design was adopted to study communities in Oron and Udung Uko local government areas in Akwa Ibom State. Using a multistage sampling procedure, data were obtained from 400 respondents using Taro Yamene sample size determination formula. Data were analysed using Chi-square (X2) statistical technique. Main findings indicated that significant relationship exists between nonparticipation of beneficiary communities in NAPEP project design, corruption, policy implementation and poverty reduction in rural communities. The findings imply that NAPEP has not significantly achieved its goal of
Accepted: June 14, 2021

Written by:

Nkpoyen Festus ${ }^{66}$

https://orcid.org/0000-0001-5110-2291

Archibong Esther P. ${ }^{67}$

https://orcid.org/0000-0002-7097-3006

Undelikwo Veronica ${ }^{68}$

https://orcid.org/0000-0002-6737-0335

Obeten Ude Bassey ${ }^{6}$

https://orcid.org/0000-0003-3457-8444

Ofem Nnana Okoi ${ }^{70}$

https://orcid.org/0000-0002-5458-7244

\section{Resumen}

El estudio investigó la brecha de desarrollo en la interacción de la política social y los problemas sociales mediante el examen del impacto del Programa Nacional de Erradicación de la Pobreza (NAPEP) en las comunidades rurales en el estado de Akwa Ibom, Nigeria. Los objetivos específicos fueron examinar la relación entre la no participación de las comunidades beneficiarias en el diseño del proyecto NAPEP a nivel comunitario, la corrupción y la estrategia de implementación de políticas para la reducción de la pobreza rural. El diseño de investigación ex post facto se adoptó para estudiar las comunidades en las áreas de gobierno local de Oron y Udung Uko en el estado de Akwa Ibom. Utilizando un procedimiento de muestreo de varias etapas, se obtuvieron datos de 400 encuestados utilizando la fórmula de determinación del tamaño de la muestra de Taro Yamene. Los datos se analizaron mediante la técnica estadística Chi-cuadrado (X2). Los principales hallazgos indicaron que existe una relación significativa entre la no participación de las comunidades beneficiarias en el diseño del proyecto NAPEP, la corrupción, la

\footnotetext{
${ }^{66}$ Department of Social Work, University of Calabar, Nigeria.

${ }^{67}$ Department of Social Work, University of Calabar, Nigeria.

${ }^{68}$ Department of Sociology, University of Calabar, Nigeria.

${ }^{69}$ Department of Social Work, University of Calabar, Nigeria

${ }^{70}$ Department of Social Work, University of Calabar, Nigeria.
} 

failed to elicit economic wellbeing priorities directly from target communities. Poverty can be reduced through accommodative and humanistic arrangements by allowing communities to identify welfare projects and eligible recipients. Rural dwellers have not experienced poverty reduction because of NAPEP development strategy gap.

Keywords: Social policy, Social problem; NAPEP, Rural communities, Poverty, Development. poverty reduction in rural communities. It has

implementación de políticas y la reducción de la pobreza en las comunidades rurales. Los hallazgos implican que NAPEP no ha logrado significativamente su objetivo de reducción de la pobreza en las comunidades rurales. No ha logrado obtener prioridades de bienestar económico directamente de las comunidades objetivo. La pobreza se puede reducir a través de arreglos humanísticos y acomodaticios al permitir que las comunidades identifiquen proyectos de bienestar y beneficiarios elegibles. Los habitantes de las zonas rurales no han experimentado la reducción de la pobreza debido a la brecha en la estrategia de desarrollo de NAPEP.

Palabras clave: política social, Problema social; NAPEP, Comunidades rurales, Pobreza, Desarrollo.

\section{Introduction}

The "world is making quantum efforts in conquering global poverty. Since 1990, a quarter of the world has extricated itself from extreme poverty with less than $\$ 1.90$ per day. As households overcome the poverty trap, an individual's social and economic lives experience qualitative improvement. Since 1990, the percentage of child mortality from preventable causes such as poverty, hunger and disease has drastically reduced "falling from more than 35,000 a day to under 15,000" (World Vision, 2019). "Although remarkable progress has been achieved in combating global extreme poverty, material deprivation and subjective wellbeing are still serious challenges in SubSaharan Africa. Even as poverty alleviation methods are still being implemented, poverty is exacerbated by conflict, poor governance, climate change and natural disasters, etc. SubSaharan African communities have consistency experienced rising incidence of people living in poverty" (World Vision, 2019)

Available statistics showed that "in 2015, 10 percent of the world's population lived on less than USD 1.90 a day, compared to 11 percent in 2013 , and nearly 36 percent in 1990 . In 2015, 736 million people lived on less than $\$ 1.90$ a day. More than half of the extremely poor live in SubSaharan Africa. The number of poor people in this region rose by 9 million, with 413 million people living on less than USD 1.90a day in 2015, higher than all other regions combined. By 2030, almost 9 out of 10 extreme poor will be found in Sub-Saharan Africa" (World Bank Group, 2019). According to the 2018 Survey by the UN Development Programme, " 1.3 billion in
104 developing countries, accounting for 74 percent of global population live in a multidimensional poverty condition" (World Goals (SDG) to end extreme poverty by 2030 is not feasible due to Nigeria's poverty condition. "The world poverty clock shows that Nigeria has surpassed India as the country recording the highest proportion of poor people in the world. Nigeria has the largest extreme poverty population" (World Bank Group, 2019). Available report by Toromade (2018) indicated that approximately 90.8 million Nigerians live on less than \$1.90 (\#684) per day. This state of poverty level exists in Nigeria even though the "approximated 643.35 million people subjected to extreme poverty globally has reduced to 592.7 million". The "90.8 million Nigerians in extreme poverty constituted 46.4 percent of its estimated 195.6 million population in 2018 (Toromade, 2018). Most of the world's biggest nations have managed to alleviate extreme poverty except Nigeria. The agenda to reduce extreme poverty globally as reported in the United Nations' Sustainable Development Goals is already at risk of meeting the target in Sub-Saharan communities (Kazeem, 2018).

Poverty in Nigeria poses one of the greatest challenges confronting our society. The 1995 World Summit for Social Development conceptualized absolute poverty as the condition characterized by severe deprivation of basic human needs including food, safe drinking water, sanitation facilities, health facilities, shelter, education and information (Nkpoyen, Nkoyo, Vision, 2019). Kazeem (2018) contended that the United Nations Sustainable Development 


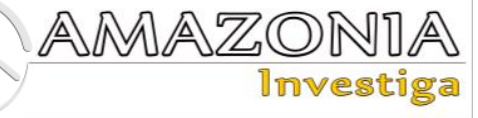

and Bassey, 2013). Despite alternative development strategies, many rural communities continue to register poor socio-economic conditions, rising inflation, lack of access to basic social services. In Nigeria, a significant proportion of economically active poor people are known to reside in rural areas. The feelings of rural dwellers towards their plight is occasioned by the inability of governments and Non-Governmental Organizations (NGOs) to efficiently harness resources to better the quality of lives, address governance challenges, forestall policy somersaults, etc. The persistence of rural poverty continues to widen the income gap between the rich and the poor and with implication for social inequality of rural dwellers, thereby increasing the magnitude of social problems in both rural and urban environments (Nkpoyen, Nkoyo and Bassey, 2013).

Poverty has been recognized as a universal social problem that must be eradicated if the world is to be humane, stable and just for the achievement of Sustainable Development Goals. While opening the World Summit for Sustainable Development (WSSD) in Johannesburg, South Africa in September 2002, Thabo Mbeki the then South African President, told delegates that "for the first time in human history, human society possesses the capacity, the knowledge and the resources to eradicate poverty and underdevelopment". Kazeem (2018) had earlier observed that poverty is no longer inevitable and should not be tolerated; that its eradication is a practical possibility. Of those countries in the top ten in Africa living in extreme poverty, "only Ethiopia is on track to meet the United Nations' SDG of ending extreme poverty by 2030. Outside the top ten, only Ghana and Mauritania are also on track with the SDG target. Of the 15 countries across the world where extreme poverty is rising, 13 are currently in Africa" (Kazeem, 2018).

Poverty elimination is a major focus of important funding agencies of the United Nations Organization: UNDP and IFAD- rural poverty reduction; UNFPA-women, reproductive health and family planning; UNICEM-women empowerment; UNICEF- children and the Girl Child. At the 1995 Copenhagen Summit, global leaders agreed to follow-up on the action and implementation program in partnership with all stakeholders for the overall reduction of poverty substantially in the shortest possible time (Ekong, 2003).
Nigerian governments have responded to issues of poverty reduction through policy pronouncements and implementation. Hence, several strategies have been designed by Nigerian governments for purposes of empowering and improving the quality of life of the inhabitants. Despite all these efforts, poverty still exists in all its multi-dimensional facets in the population. Some of Nigeria's poverty alleviation social policies included: Operation Feed the Nation (OFN), National Accelerated Food Production Programme (NAFPP), Green Revolution, National Directorate of Employment (NDE,), Directorate of Food, Roads and Rural Infrastructure (DFRRI), Agricultural Development projects (ADB), Nigerian Agricultural and Cooperative Bank (NACB), National Fadama Development Programme (NFDP), The Nigerian Special Programme for Food Scarcity (SPFS), Family Support Programme (FSP, formerly Better Life Programme, BLP), People's Bank, Structural Adjustment Programme (SAP), Oil Mineral Producing Area Development Commission (OMPADEC, now Niger Delta Development Commission- NDDC), Mass Transit Programme (MTP), Agricultural Development Project (ADP), Agricultural Credit Guarantee Scheme (ACGS) etc.

The National Poverty Eradication Programme (NAPEP) policy framework was formulated in 2000 by the Obasanjo Administration. To achieve its objectives, NAPEP designated the following components: Youth Empowerment Scheme (YES) targeted at helping to address the problem of unemployment among the youths of Nigeria; Capacity Enhancement Scheme (CES) designed for people who have basic skills but need additional resources to avoid poverty and ensure wealth creation. Through CES, beneficiaries are provided with credit information and tools/equipment that may be needed for their trade, occupation or businesses; Community Enlightenment and Sensitization Scheme (COMESS) which is a collection of programs that employ various media to take the message of modest public support for self- help and active participation in poverty reduction and wealth creation activities to communities, using Radio, and Television programs, information brochure, workshops/seminars, and mobile video units; Social Welfare Service Scheme (SOWESS) is designed to promote projects that improve the social and personal well-being of Nigerians; Rural Infrastructure Development Scheme (RIDS) deals with the provision of potable and irrigation water, transport (rural and urban), rural energy and power supply; National 
Resource Development and Conservation Scheme (NRDCS)"

The "past social policies for alleviating poverty have not been successful because of the factors such as the exclusion of program beneficiaries from project design, corruption, poor implementation strategies and poor funding. Those multi-sectorial schemes have failed to transform and modernize rural communities in Akwa Ibom state of Nigeria. Rural communities in Udung Uko and Oron local government areas of Akwa Ibom State have remained in a perpetual state of impoverishment. The people in these communities lack access to such fundamental necessities of life such as health services, education, potable water supply, minimum nutrition requirement to stay alive, and comfortable shelter, etc. The communities face social infrastructural deficiencies and low standard of living amid government poverty eradication policy" (Nkpoyen and Bassey, 2012.

The increasing incidence of poverty in rural areas has seriously hampered the optimal realization of rural dwellers potentials to embrace a better quality of life. Consequently, governments at all levels have planned, initiated and executed several social policies ostensibly aimed at alleviating poverty. Experience so far demonstrates that rather than transform and bring about improvement in the standard of living, the rural communities have contrary to the objectives of social policies of poverty alleviation, continued to be impoverished. The silent majority of the rural populace continue to become victims of neglect, deprivation, and exploitation. Existing poverty alleviation social policies have not translated into tangible social benefits in the form of improved welfare. As laudable as these social policies have been, observably, the people's level of living has not positively changed. In other words, rural dwellers especially have not experienced "sustainable access to resources to tackle basic needs such as adequate access to food, potable water, health facilities, educational opportunities, housing, time for individual participation and social integration. Poverty situation seems to worsen as more policies aimed at alleviating it are initiated and implemented" (Nkpoyen and Bassey, 2012). Based on the issues above, the study was carried out to determine the extent to which the National Poverty Eradication Programme has been able to bridge the gap between social policy and social problems in rural communities of Akwa Ibom State, Nigeria.

\section{Literature survey}

\section{Social Welfare Policy of NAPEP and Poverty Reduction}

Poverty eradication has remained dominant in the agenda of development scholars as demonstrated in its emphasis in the just concluded Millennium Development Goals (MDGs) and now Sustainable Development Goal (SDGs). Reducing poverty in Nigeria has always been an agenda of the government for the past decades. The poverty level in Nigeria rose from 0.28 to 0.43 percent between 1980 and 1992. The situation deteriorated in 1996 to an average of 0.66 percent (Aluko,2003). The effort to mitigate the poverty situation resulted in the establishment of the National Poverty Eradication Programme in 2001. The poverty reduction components of NAPEP included: "Youth Empowerment Scheme (YES), Rural Infrastructure Development Scheme (RIDS), Social Welfare Service Scheme (SOWESS) and Natural Resources Development and Conservation Scheme (NRDCS) (Antai and Anam, 2014). As part of NAPEP's implementation strategy in 2001, it received a take-off grant of $\$ 6$ billion. The money was utilized to establish NAPEP structures in 36 states, including Abuja (Federal Capital Territory) and the existing 744 local government councils. The money was also used in NAPEP employment generation intervention which led to the training of 100,000 youth, attachment of 50,000 unemployed Graduates in various places of work, training of over 5000 people in fashion design, the establishment of rural telephone networks in 125 local government areas. Additionally, the money aided the delivery of KEKE-NAPEP three-wheeled vehicle involving 2000 units in all state capitals. Also, 147 youth information centers were established across the senatorial district and the delivery of informal micro-credit ranging from $\$ 10,000$ to $\$ 50,000$ to 10,000 beneficiaries mostly women" Adisa (2013)

The "central aim of social welfare policies is to reduce poverty. Every major industrialized nation has a set of programs that transfer between $10 \%$ and $30 \%$ of the country's gross domestic product (GDP) among the populace, a key goal of which is to improve the well-being of those at or near the bottom of the income distribution. Do these programs work? Several analysts contend that social welfare policies do indeed help to alleviate poverty. But the past two decades have witnessed a growing chorus of criticisms about the actual impact of poverty reduction interventions in the rural environment. Some 


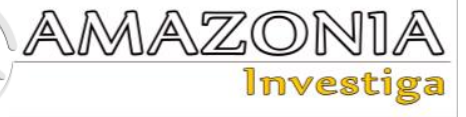

averred that too little of the income that is transferred reaches the poor. Others suggested that by providing a safety net, such programs sap the initiative of the poor and thereby creating a 'poverty trap'. Existing arguments and evidence in rural communities of Sub-Saharan African support the view that social welfare programs have failed to reduce poverty particularly because the programs have been elitist, urban focus isolating the rural communities in conceptualization, design, and implementation. "Many reasons have been advanced for the negligible poverty-reduction impact of social welfare policies: non -involvement of beneficiary communities in poverty alleviation programs, failure to ensure the successful implementation of the various programs and policies, slow economic growth, economic mismanagement, infrastructural deficiencies, weak political commitment, undue incursion by political sentiments (World Bank Group, 2019). The policies also pay little attention to the framework of allocation of funds, sustainability aspects and the needed collaborative arrangement. Corruption has been implicated by Ajibola et al. (2018) as a cause of poor implementation of the poverty program in Nigeria (Nkpoyen, Bassey \& Uyang, 2014a).

\section{Non-participation formulation/implementatio reduction}

The success of social welfare policy depends on the level of community participation in such poverty alleviation projects. Asserted that most social welfare policies by various governments in Nigeria at different times have produced minimal results in spite of the huge amount of resources committed into them. Adisa (2013) realized from his study that past social welfare policies failed because the intended beneficiaries were not always involved in the program's designs. Participation enables poverty alleviation programs/projects to be erected on the strength, traditional beliefs and values of communities concerned (their social organizations, indigenous skills, aspiration, local leadership and energy potentials) thereby practically equipping villages with the capacity to handle their affairs on step by step basis. Participation implies that the poverty alleviation project has taken cognizance of the socio-cultural milieu of the community. It empowers communities in the sense of increasing their capacity to define and analyze poverty alleviation efforts in line with community felt needs (Ajibola et al, 2018).
Participation by beneficiary communities serves as a vehicle for psychological satisfaction, motivation, and mobilization. By being involved in project decisions which concern their wellbeing, people can see that they have some control over the project and expected outcomes. This, in turn, makes it easier for local and external human materials to be tapped, pooled and mobilized for poverty reduction purposes. Antai \& Anam (2014) argued that in spite of all the efforts by various governments to design social welfare policy, poverty continues unperturbed. The policies have been unsuccessful because the center point, the views of the people supposed to benefit are not considered in policy design and implementation strategies. In most parts of Nigeria, social policies by the federal government have been made to empower as many individuals as possible, yet the level of poverty has been sustained because the beneficiaries are neglected in program design and implementation. Adisa (2013) contended that "if poverty alleviation programs are to be successful, careful attention has to be given to some design issues. They suggested that all poverty-related programs/ policies should determine the form of poverty to be addressed, identify possible approaches to be adopted, apply suitable principles for selecting particular programs, determined how the intended beneficiaries are to be identified and involve them in such program design". Policies and programs dealing with poverty should involve the grassroots, the beneficiaries through a kind of dialogue where it will involve majority and evaluation. This will make the people to be adequately informed of the objectives, plans and eventual execution processes.

Several social welfare policies to address poverty have been introduced in the past decades without achieving any meaningful results. Several poverty reduction projects were expected to impact positively on the rural poor but were poorly designed and implemented because the prime beneficiaries were excluded (Aderomu, 2010) Poverty alleviation projects in which the people are involved and articulate their needs themselves have better chances of being understood, accepted, supported and maintained by the community. Ajibola et al. (2018) argued that the need for designing sustainability into poverty alleviation policies cannot be overemphasized. Policy sustainability has several dimensions- financial, institutional, political and environmental. Social welfare policies should permit active community participation in project identification, planning, implementation, and appraisal. The underlining 
assumptions are that people are willing to cooperate and work with one another; voluntarily contribute labor, time, materials. Moreover, people organize best around problems or needs they consider important. The level of success of social welfare policy depends on the extent it meets people felt needs.

\section{Corrupt practices and poverty reduction}

Many social welfare policies have failed because those that are to manage such programs are either misappropriating or mismanaging the funds. "Government officials embezzle funds meant for poverty reduction programs and often make the program a family affair. This makes beneficiaries to suffer unduly. NAPEP (National Poverty Eradication Programme) and YES (Youth Empowerment Scheme) have been very lofty in its outlook but more often, it is a badly implemented strategy. Many officials in the National Poverty Eradication Council (NAPEC) without proper documentation, release huge funds to non-existing beneficiaries, unrecognized and ghost persons. It is on record that in some local government areas, many people benefit from the money made available to the area without having anything to show. They do this in connivance with the officials. Corruption is a direct hindrance to an effective poverty reduction strategy in Nigeria. Corruption is generally acknowledged as having adversely affected previous poverty alleviation efforts in the country" Abdullahi, 2004; Okhira \& Obadeyi (2015)

Omoniyi (2013) stressed "that the manifestations and problems associated with corruption and other sharp practices affecting social policies are overwhelming. The effect of corruption is both direct and indirect on poverty increase. The direct effect follows from the reduction or misapplication of resources which lowers growth rates and there are no outputs and incomes to redistribute, so poverty escalates. The indirect effect is that the poor are denied resources and access to facilities that could have been provided through the judicious application of siphoned/diverted resources".

Obadan (1997) observed "that the earliest poverty alleviation programs were the 1972 Gen. Yakubu Gowon's National Accelerated Food Production Programme and the Nigerian Agricultural and Cooperative Bank devoted to funding agriculture. The Operation Feed the Nation of Obasanjo in 1976 expended much money and effort in getting ill-prepared university undergraduates to go to the rural areas to teach the peasant farmers how to farm". Aliu (2001) asserted that the 1979 Shagari's Green Resolution Programme had the twin objectives of curtailing food importation while boosting crop and fiber production. Many senior civil and military officers benefited. When the program ended in 1983, 2 billion naira taxpayers' money was wasted. Anriquez \& Stamoulis (2007) stated that in 1966, Babangida established the Directorate of Food, Roads and Rural Infrastructure (DFRRI) for rural development. The project gulped N 1.9 billion (about $\mathbb{N} 80$ billion today's value) without Nigerians benefiting from them. Various projects were set up for poverty alleviation purposes such as the Peoples Bank of Nigeria and the Community Bank of Nigeria. Babangida wasted more than $\mathrm{N}$ 100 billion in phantom projects. Neither did these financial institutions lived up to their expectations nor did they actualize their aims. Babangida's wife set up the Better Life Programme and ended up making millionaires out of the BLP officials and friends. Better Life for rural women became the better life for rich women".

Omoniyi (2013) stated that corruption is a problem in social welfare policy design and implementation for poverty reduction. He reported that if Buhari had been honest in his management of the Petroleum Trust Fund (PTF) the number of financial resources at his disposal would have been enough to alleviate poverty

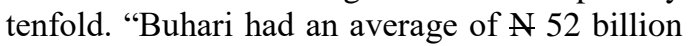
every year to spend. At the end of the PTF program, Nigeria's poverty and underdevelopment levels worsened. WilsonOsigwe \& Oluwole (2016) maintained that corruption and abuse of positions and privileges have long been features of past and present poverty reduction strategies. Fukada-Parr (2003) argued that corruption is behind the rising incidence of poverty reverberating in rural areas.

Nkpoyen, Bassey, and Uyang (2014b) contended "that corrupt practices have led to the implementation of badly-designed social welfare policies with no economic or commercial viability. Cost escalation has resulted in pricing policies which have kept the services beyond the reach of the ordinary masses who were expected to be the beneficiaries". In some cases, "projects have been abandoned, both completed and uncompleted after substantial public funds have been expended" (Ihejiamaizu, 2002). Many projects have been abandoned at "communities and local governments, even in our universities. The reason being that funds were diverted to serve private or group interest. Therefore, these 


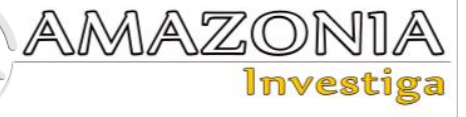

factors have perpetuated a vicious circle of poverty and underdevelopment in Sub-Saharan African Communities. Scarce resources instead of being allocated are wasted on projects without direct bearing on poverty reduction" (Ihejiamaizu, 2002).

\section{Poor Policy Implementation and Poverty Reduction}

The effectiveness of social welfare policy has been constrained by poor implementation brought about "by inadequate funding from local government areas and lack of equipment and trained manpower" (Aliu, 2001). The failure to ensure successful implementation of the various policies has deepened the incidence of poverty. Poverty alleviation policies have failed "because of poor management of the nation's resources. There have been instances of glaringly poor execution of government policies especially those aimed at the provision of social welfare services and those aimed at the provision of economic infrastructure".(Aliu, 2001).

Many poverty reduction programs suffer a lot of setbacks due to undue incursion by political sentiments. Toromade (2018) maintained that until issues of poor implementation of policies and programs in Nigeria are given urgent attention, rural areas will continue to be affected by abandoned poverty alleviation projects. In the views of most implementers of policies associated with poverty often do it without experience. As observed by Omoniyi (2013) most poverty reduction policies are not implemented due to lack of strong political commitment to the poverty reduction goals Corroborating Agwu \& Kadiri (2014) conclusions, Ajibola et al. (2018) argued "that for there to be a meaningful impact of social welfare policy on poverty, poverty reduction programs and measures need to be implemented within the framework of rapid broad-based economic growth with equity, sound economic management, and good governance. $\mathrm{He}$ recommended that attention be given to poverty alleviation objectives in national development plans with strategies and measures integrated into the country's overall development/policy management framework".

Poor implementation of social welfare policies has plagued Nigeria for many years now (Abdullahi (2004)). Aderomu (2010) observed that given the present accelerated and concerted efforts at fighting the menace of poverty in Nigeria, poverty reduction strategies will continue to fail. The implementation strategies have failed to enhance the quality of productive life. As commented by Agboola (2008), "social welfare policies are constrained by the absence of effective collaboration and complementation among the three tiers of government". These policies have failed to meet the expectations of Nigerians due to poor implementations occasioned by partisan considerations, corruption or other malpractices. The success of these social policies has been particularly constrained by its top-bottom planning. This engineering planning model has been the bane of social policies. To be successful, the social welfare policy should aim to address the specific needs of people, interpret them in the context of their knowledge, design what should be done, offer technical advice and plan for specific activities that would meet the needs of the people. Omoniyi (2013) averred that facilitating the success of social welfare policy lies in its proper conception and a firm commitment to its cause and course.

\section{Theoretical framework}

Human Development (capability) approach

The United Nations Development Programme (UNDP) launched the Human Development Report to shift focus from development as economic growth to development in terms of core values. Development goes beyond the level of income to "embrace the extent to which people utilize the income to attain satisfaction in life. Human development addresses poverty reduction, sustainable development, gender inequalities and governance" (Fukada-Parr, 2003). Human Development is associated with Sen's capability approach that addresses development challenges from the perspective of inequality. The capability approach conceptualizes human life in terms of functioning; it examines the quality of life by assessing its capability to function. "An assessment of the quality of life translates to a functioning and the capability to function. Human Development is people-centered. In improving people's condition of existence, their choices must be enlarged" (Streeten, 1994).

The functioning of human beings is guaranteed through potentiality to escape morbidity and mortality, adequate nourishment, knowledgeable and ability to achieve self-respect and participate in community life. Development strategies must be capable of fostering better life by dismantling obstacles such as illiteracy, ill-health, inability to access resources and lack of political freedom to choose between alternative ways of living (Fukada-Parr, 2003). This means that social 
welfare policy such as the National Poverty Eradication Programme (NAPEP) has the potential to enhance economic wellbeing and improve the overall living conditions of people. NAPEP is expected to operate on the reality that people are both the means and end in the process of development.

\section{Hypotheses}

1. Non-participation of beneficiary communities in poverty eradication project design and implementation at the community level has no significant association with poverty reduction in rural areas of Akwa Ibom State.

2. Corruption has no significant association with poverty reduction in rural communities of Akwa Ibom State.

3. Poor policy implementation strategy has no significant association with poverty reduction in rural communities of Akwa Ibom State.

\section{Methodology}

\section{Study area}

Oron local government area is located between longitude $8^{014^{\prime} \mathrm{E} \text { and }} 8^{0} 16^{\prime} \mathrm{E}$ and latitude $4^{0} 47^{\prime} \mathrm{N}$ in the Akwa Ibom state of Nigeria. It has a population of over 142, 640 people (National Population Commission NPC (2006), and a land area of 123,917 square meters. The forest is rich in cedar, iroko, mahogany and camwood trees. There are four clans namely: Afaha Okpo clan, AfahaUbodung clan, Afaha Ibighi clan and Idua clan. Out of these, Afaha Okpo has ten (10) villages, Afaha Ibighi one, Afaha Ubodung one while Idua clan has five (five) villages Aderomu (2010).Udung Uko local government area was created out of Oron local government area of Akwa Ibom state on $6^{\text {th }}$ December 1996. It has a total area of about 112,000 square kilometer excluding the territorial waters. It has a population figure of 106,000 (NPC, 2006). Its headquarters is Eyo-fin. There are two clans namely; the AfahaOkpo clan and Ubodung clan. Emanating from the clans are twenty-eight villages out of which twenty-four belong to Afaha Ubodung clan. The forest serves as a habitat for wildlife which includes parrots, monkeys, crocodiles, cobra and python.

In both local government areas, secret societies constitute an integral part of the government. Ekpe Society was employed in pre-colonial days as an instrument for the enforcement of traditional authorities in both local government areas. Akata is an important society that equally plays a key political role in society. Another society is the women's secret society called IbanIsong. Also, is Nka Society made up of young men with the same age range? Both local government areas have landed as the mainstay of their economy. The land in which they occupy is an area of fertile forest which makes its exploitation rewarding. The land is a communal property resulting from close kinship and friendly ties. "The people are predominantly farmers and fishermen. Production is backed by the need for subsistence and little surplus for exchange". Stockbreeding is practiced including goats, sheep, poultry and hump fewer cattle. Some proportion of the population is engaged in fishing, hunting, plaiting, carpentry, and production of local gin. There is a welldeveloped market system. The people have a strong belief in witchcraft (Ifot).

\section{Research design}

The researcher purposively selected these two local government areas based on prior knowledge of non-involvement in NAPEP activities. Thus the sample population comprised all communities in Oron and Udung Uko local government areas.

The study adopted a multi-stage sampling procedure. Firstly, the 6 clans formed the six strata of the study. There are 4 clans and 17 villages in Oron local government area (Afaha Okpo clan- 10 villages, Afaha Ubodung clan- 1 village, Afaha Ibighi clan- 1 village and Idua clan- 1 village). There are 2 clans in UdungUko local government area (Afaha Okpo clan-4 villages, Ubodung clan-24 villages). The researcher purposively studied all the clans with 1 village, which is the only village in Afaha Ubodung and the only village in Afaha Ibighi were purposively studied. For the clans with more villages, the researcher adopted a hat and draw method of simple random sampling to select 2 villages each. Thus, from Oron local government area, 10 villages were selected, from Udung Uko local government area, 10 villages were selected. This amounted to 20 villages and the 20 villages formed the 20 clusters of the study. To select the actual respondents for the study, a systematic sampling procedure was adopted. The researcher enumerated the living houses in the villages and selected only oddnumbered houses. Through this method, 40 households were selected from each village. Only one adult male or female in each household participated in the study. Altogether there were 48 participated in the focus group discussion 


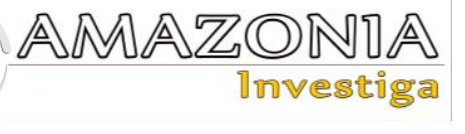

(FGD). Therefore, 400 respondents participated in the questionnaire study while 48 were involved in the FGDs. The total number of subjects who took part in the study were 448 .

The main research instruments were Assessment of National Poverty Eradication Programme Scale (NAPEPS), a 26- item questionnaire and a 13 item FGD guide. The research instrument was a Yes or No response scale. Chi-Square analytical technique was used to analyze the data.

\section{Limitations}

1. The study was conducted in the wet season. The difficult terrain and the deplorable nature of the road prolonged the duration of data collation.

2. The cultural festivals of the community constrained women from participating in the study initially. It was necessary to wait for such cultural festivals to end to enable women to participate to foster gender balance.

\section{Major Findings}

1. Non-participation of beneficiary communities in NAPEP intervention at the local level has affected poverty reduction in rural areas of Akwa Ibom State, Nigeria.

2. Corrupt practices in NAPEP is responsible for its failure to reduce poverty in rural areas of Akwa Ibom State, Nigeria.

3. Poor policy implementation strategy has significantly affected NAPEP's effort of poverty reduction in rural areas of Akwa Ibom State, Nigeria

4. There is a gap between social policy and social problem remediation in Nigeria.

5. Development strategy gap can be bridged by eliciting social welfare priorities directly from target communities; allowing them identify projects and eligible recipients; expanding resources available to the poor (through credit, social funds, capacity building.etc.

\section{Analysis/results}

\section{Hypothesis 1}

There is no significant association between nonparticipation of the beneficiary community in project design/implementation at the community level and poverty reduction.

Table 1.

Contingency table showing association between non-participation of beneficiary communities in project design/implementation at the local level and poverty reduction.

\begin{tabular}{llllll}
\hline Cell & $\mathrm{O}$ & $\mathrm{E}$ & $\mathrm{O}-\mathrm{E}$ & $(\mathrm{O}-\mathrm{E})^{2}$ & $(\mathrm{O}-\mathrm{E}) 2 / \mathrm{E}$ \\
\hline 1 & 55 & 46.85 & 66.4225 & 66.4225 & 1.42 \\
2 & 35 & 43.15 & -8.15 & 66.4225 & 1.54 \\
3 & 30 & 52.05 & -22.05 & 486.2025 & 9.34 \\
4 & 47.95 & 22.05 & 486.2025 & 10.14 \\
5 & 70 & 41.64 & 6.64 & 44.0896 & 1.06 \\
6 & 35 & 39.36 & 6.64 & 44.0896 & 1.15 \\
7 & 45 & 49.4520 .55 & 422.3025 & 8.54 & \\
8 & 70 & 45.55 & -20.55 & 422.3035 & 9.27 \\
total & 25 & & & & 42.46 \\
\hline
\end{tabular}

\section{Source: field survey. 2019}

Calculated $\left(\mathrm{X}^{2}\right)$ value $=42.46$

Critical $\left(\mathrm{X}^{2}\right)$ value $=7.81$

Degree of freedom $=3$

Level of significance

Decision Rule

If the calculated $\left(\mathrm{X}^{2}\right)$ valve is greater than the critical(X2) valve, at 0.05 level of significance with specified degrees of freedom, the null hypotheses (Ho) will be rejected while the alternate hypothesis (Hi) will be accepted signifying a positive relationship between the variables of the hypothesis. But if otherwise accept the null hypothesis (Ho) and reject the alternate hypothesis.

\section{Conclusion}

Since the calculated $\left(\mathrm{X}^{2}\right)$ valve of 42.46 was found to be greater than the critical $\left(\mathrm{X}^{2}\right)$ valve of 7.81 needed at 0.05 level of significance, with 3 degree of freedom, the null hypothesis which states that there is no significant association between non-participation of beneficiary 
communities and poverty reduction promotion among rural dwellers in terms of improved income was rejected in favor of the alternate hypothesis. This means that the non-participation of beneficiary communities has a significant association with the poverty reduction among rural dwellers. It also implies that through the participation of beneficiary communities, the socio-economic wellbeing of the rural dwellers in terms of income has been improved.

\section{Hypothesis 2}

There is no significant relationship between corruption (in terms of embezzlement of funds, funds poorly channeled or misapplied, funds released to non-existing beneficiaries, misapplication of resources, denial of access to resources by the poor, weak accountability) and poverty reduction.

Table 2.

Contingency table showing an association between corruption and poverty reduction.

\begin{tabular}{llllll}
\hline Cell & $\mathrm{O}$ & $\mathrm{E}$ & $\mathrm{O}-\mathrm{E}$ & $(\mathrm{O}-\mathrm{E})^{2}$ & $(\mathrm{O}-\mathrm{E}) 2 / \mathrm{E}$ \\
\hline 1 & 165 & 98.84 & 66.16 & 4377.1456 & 44.29 \\
2 & 30 & 96.16 & -66.16 & 4377.1456 & 45.52 \\
3 & 20 & 86.16 & 86.16 & 4377.1456 & 50.80 \\
4 & 150 & 83.84 & 66.16 & 4377.1456 & 52.21 \\
total & 365 & & & & 192.82 \\
\hline
\end{tabular}

Source: field survey, 2019

Calculated $(\mathrm{X} 2)$ valve $=192.82$

Critical $(\mathrm{X} 2)$ valve $=3.84$

Degree of freedom $=1$

Level of significance $=0.05$

Decision rule

If the calculated $\left(\mathrm{X}^{2}\right)$ valve is greater than the critical (X2) value, at 0.05 level of significance with a specified degree of freedom, the null hypothesis (Ho) will be accepted signifying a positive relationship between the variables of the hypothesis. But if otherwise accept the null hypothesis $\left(\mathrm{H}^{\circ}\right)$ and rejected the alternate hypothesis.

Since the calculated $\left(\mathrm{X}^{2}\right)$ valve of 192.82 was found to be greater than the critical $\left(\mathrm{X}^{2}\right)$ valve of
3.84, needed at 0.05 level of significance with 1 degree of freedom, the null hypothesis which states that there is no significant relation between corruption- in terms of embezzlement of funds, funds poorly applied or misapplied, funds released to non- existing beneficiaries, misapplication of resources, denial of access to resources by the poor, weak accountability has no significant association with poverty reduction was rejected in favor of the alternate hypothesis. This means that corruption has a significant association with socio-economic wellbeing of rural dwellers

\section{Hypothesis 3}

Poor policy implementation has no significant association with poverty reduction.

Table 3.

Contingency table showing association between poor policy implementation and poverty reduction.

\begin{tabular}{llllll}
\hline Cell & $\mathrm{O}$ & $\mathrm{E}$ & $\mathrm{O}-\mathrm{E}$ & $(\mathrm{O}-\mathrm{E})^{2}$ & $(\mathrm{O}-\mathrm{E}) 2 / \mathrm{E}$ \\
\hline 1 & 130 & 108.97 & 21.03 & 442.260 & 4.06 \\
2 & 85 & 106.03 & -21.03 & 442.260 & 4.17 \\
3 & 55 & 76.03 & -21.03 & 442.2609 & 5.82 \\
4 & 95 & 73.97 & 21.03 & 442.2609 & 5.98 \\
\hline
\end{tabular}

Source: field survey. 2019 


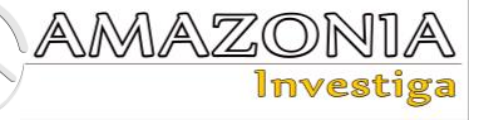

Calculated $(\mathrm{X} 2)$ valve $=20.03$

Critical $(\mathrm{X} 2)$ valve $=3.84$

Degree of freedom $=1$

Level of significance $=0.05$

\section{Decision rule}

If the calculated $\left(\mathrm{X}^{2}\right)$ valve is greater than the critical $\left(\mathrm{X}^{2}\right)$ valve at 0.05 level of significance with specified degrees of freedom the null hypothesis (Ho) will be rejected while alternate hypothesis (Hi) will be accepted signifying a positive relationship between the variables of the hypothesis. But if otherwise accept the null hypothesis 9Ho) and reject the alternate hypothesis (Hi)

\section{Conclusion}

Since the calculated $\left(\mathrm{X}^{2}\right)$ valve of 20.03 was found to be greater than the critical $\left(\mathrm{X}^{2}\right)$ valve of 3.84 needed at 0.05 level of significance, with 1 degree of freedom. This means that the null hypothesis which states that poor quality implementation- in terms of failure to target the poor specifically, lack of targeted mechanisms for the poor, political /policy instability, inadequate coordination of program/ overlapping functions, budgetary/management problems and inappropriate program design has no significant association with poverty reduction was rejected in favor of the alternate hypothesis.

\section{Discussion}

\section{Non-involvement of beneficiary communities in poverty program formation at the local level and poverty reduction}

The result of the analysis of hypothesis one revealed a significant association between the non-involvement of beneficiary communities in poverty alleviation program formulation at the local level and poverty reduction. These findings support Ntui (2005) that NAPEP and past social welfare policies of poverty reduction have failed because the intended beneficiaries are not always excluded from project conception and implementation. The findings agree with Omoniyi (2013) who observed that social policies to alleviate should be seen as an entire process in which people concerned to take part in the initiation and implementation of decisions. The findings validate Okhira \& Obadeyi (2015) conclusion that participation of beneficiaries enable social welfare policies to be erected on the strength, traditional beliefs and values of communities (their social organizations, indigenous skills, aspiration, local knowledge, and energy) thereby practically equipping villagers with the capability to handle their affairs on step by step basis.

\section{Corruption and poverty reduction}

The result of the analysis of hypothesis two indicated that a significant association exists between corruption (manifested in embezzlement of funds, funds diverted or poorly channelled, funds released to non-existing beneficiaries, misapplication of resources, denial of access to resources by the poor, weak accountability) and poverty reduction. These findings support Ihejiamaizu (2002) "that much money has been spent on NAPEP and its Youth Empowerment Scheme (YES) to no avail. Corrupt practices have led to the implementation of badly designed projects. Scarce resources instead of being allocated and judiciously used on alleviating poverty are wasted if not outrightly diverted on projects that have little or no direct bearing on poverty reduction". The findings agree with Apata et al (2010) that projects are bound to be poor because the contractor or consultant who has not been forced to spend so much on bribes to secure the job will try to recover his money by using cheap and inferior materials on implementing the project. The findings are in tandem with that the problem of poverty reduction programs in Nigeria is corruption and embezzlement. Olamola \& Carim (1999) observed that NAPEP has been on the line for many years without recording any satisfactory result because of corruption.

\section{Poor policy implementation and poverty reduction}

The statistical analysis of hypothesis three revealed that a significant association exists between poor policy implementation and poverty reduction. The findings are in harmony with Wilson-Osigwe \& Oluwole (2016) who stated that until issues of poor implementation of policies and programs in Nigeria are given urgent attention, poverty alleviation projects will continue to be abandoned. Similarly, Olamola \& Carim (1999) reported "that the incidence of poverty remains very high notwithstanding the existence of various social welfare policies. Policies have failed because of lack of targeted mechanisms for the poo; political and policy instability have resulted in frequent policy changes and inconsistent implementation" Apata et al (2010) findings have been confirmed by this study too. Apata et al observed that the effectiveness of poverty reduction programs in Nigeria has consistently been hampered by 
inadequate funding and overlapping functions ultimately leading to institutional rivalry and conflicts.

\section{Conclusion and recommendation}

The study concluded that NAPEP as a social welfare policy has been ineffective in poverty reduction especially in rural communities because it is constrained by the non-involvement of beneficiary communities in project design, corruption, and poor implementation. Most communities are not even aware of the existence of NAPEP. Hence, the reduction of rural poverty rests on the commitment of the ruling/governing elites in ensuring the availability of an effective monitoring mechanism at the community level controlled by the community itself. Poverty cannot be eradicated but governments and civil society organizations can try to reduce the incidence and severity through various accommodative and humanistic arrangements such as eliciting social welfare priorities directly from target communities; allowing communities to identify welfare projects and target recipients. The socio-cultural environment of benefiting communities must be factored into the design of poverty alleviation programs by adopting the bottom-top approach. The government should be committed to the due process approach to ensure that corrupt practices in Poverty Reduction Programmes are eliminated. Again, resources available to the rural poor should be expanded through credit, social funds, capacity building. Civic capacities of communities should be strengthened by nurturing organisations that represent them.

\section{Future Scope of Study}

1. Development is both political and community decisions. The intellectual elites have a significant role to play in rural poverty reduction. Macro social factors determine many of the problems, successes, and failures of rural reconstruction and poverty alleviation. The interaction between the characteristics and the attitudes of the governing elites, the existing communitybased organizations and the willingness of community members can determine the rate of poverty reduction in rural communities. The tripartite linkage can determine the success or failure of rural poverty reduction efforts. Leaders' positive inclination, level of commitment and sincerity together with indigenous development associations and community participation may be necessary conditions for rural poverty reduction. This tripartite linkage should be the future scope of the study.

2. The rural environment's incapability to mobilize its resources for its development, the extent to which it can influence the center in policymaking and resource allocation and the extent to which it is organized to create a collective consciousness for assertiveness and participation in the process of rural development for poverty reduction is a sufficient condition for poverty reduction policy failure. Rural Sociologists would need to explore this dimension

\section{Acknowledgments}

Many thanks to the University of Calabar for creating an enabling environment for research and knowledge advancement. I also appreciate my co-authors, scholars whose works are cited in this article, the good people of Akwa Ibom State and the editorial Team of this Journal.

\section{Conflict of Interest}

The authors declare no conflict of interest.

\section{References}

Abdullahi, M. (2004). The Design and Management of Poverty Alleviation Projects in Africa. Washington D.C.: Economic Development Institute.

Aderomu, J. A. (2010). Local Government and Poverty Eradication in Rural Nigeria. Canadian Social Science, 6(5), 200-208

Adisa, B. O (2013) Assessing the contribution of Community-Based Natural Resources Management Programme to environmental sustainability in Ondo State, Nigeria. African Journal of Environmental Science and Technology, 7(10), pp. 932-937

Agboola, T (2008) The participation of the rural poor in rural development: a theoretical construct. The Nigerian Journal of Social Studies, 30(2), 15-25

Agwu, M. E. \& Kadiri, K. I. (2014). Analysis of critical strategic factors for successful implementation of poverty alleviation programmes in Nigeria. International Journal of Computational Engineering \& Management, 17(1), 1-9

Ajibola, A., Loto, M. \& Enilolobo, O. (2018) Poverty and Inequality in Nigeria: Implications for Inclusive Growth. Nile Journal of Business and Economics, 4(9), https://journal.nileuniversity.edu.ng/index.php/ NileJBE/article/view/160 


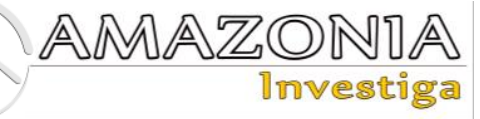

Aliu, A. (2001). National Poverty Eradication Programme (NAPEP): Completion, Implementation, Coordination and Monitory; Abuja, NAPEP Secretariat.

Aluko, M. A. O. (2003). Strategies for poverty reduction in Nigeria. Journal of Social Sciences, 7(4), 255-266. Retrieved from https://www.tandfonline.com/doi/abs/10.1080/0 9718923.2003.11892388

Anriquez, G \& Stamoulis, K (2007) Rural development and poverty reduction: is agriculture still the key? Electronic Journal of Agricultural and $\mathrm{t}$ www.fao.org/es/esa/eJADE Development Economics, 4 (1), pp. 5-46

Antai, A. S. \& Anam, B. E. (2004). National Poverty Eradication Programme and poverty reduction in Nigeria: empirical investigation of the programme impact in Cross River State. International Journal of Human Resource Studies, 4,3, 269-279 Retrieved from http://www.macrothink.org/journal/index.php/ij hrs/article/view/5629

Apata, T. G., Apata, I, O, Igbalajobi, O. A. and Awoniyi, S. M. O. (2010) Determinants of rural poverty in Nigeria: Evidence from small holder farmers in South-western, Nigeria. Journal of Science and Technology Education Research, $\begin{array}{lllll}\text { 1(4), } & \text { pp. } & 85 & - & 91,\end{array}$ http://www.academicjournals.org/JSTER

Ekong, E. E. (2003). An Introduction to Rural Sociology, Uyo: Dove Education Publishers. Fukada-Parr, S. (2003). The human development paradigm: operationalizing Sen's ideas on capabilities. Feminist Economics 9, 2-3, 361317.

Ihejiamaizu, E. C (2002) "Sociology of Nigerian Rural Society" Mbaise Rd. Owerri Imo-State, Nigeria: African Scholars publishing company. Kazeem, Y. (June 25, 2018). Nigeria has become the poverty capital of the world. Quartz Africa. Retrieve from: https://qz.com/africa/1313380/nigerias-has-thehighest-rate-of-extreme-poverty-globally/ National Population Commission (NPC) (2006) Nigeria National Census: Population Distribution by Sex, State, LGAs and Senatorial District: 2006 Census Priority Tables (Vol. 3). http://www.population.gov.ng/index.php/public ation/140-popn-distri-by-sex-state-jgas-andsenatorial-distr-2006

Nkpoyen, F. \& Bassey, G. E. (2012). Microlending as an empowerment strategy for poverty alleviation among women in the Yala local government area of Cross River State, Nigeria. International Journal of Business and Social Science, 3(18), 233-241.

Nkpoyen, F., Bassey, G. E. \& Uyang, F. A. (2014a). Health capital and poverty reduction in rural Cross River State, Nigeria. International Journal of Education and Research, 2 (5), 357-372.

Nkpoyen, F., Bassey, G. E., \& Uyang, F. A. (2014b). Entrepreneurship, corruption and the challenge of development in Nigeria. European Journal of Business and Social Sciences, 3 (3), 104-112.

Nkpoyen, F., Nkoyo, E.I. \& Glory, E. B. (2013). Impediments to sustainable rural development in materially backward economy of Uyo local government area, Akwa Ibom State, Nigeria. Research Journal of Social Sciences and Management, 3(4), 49-60.

Ntui, O. E (2005) Assessment of the level of community participation in rural development projects within the support zone of Cross River National Park (Unpublished M.Sc. thesis submitted to Graduate School), University of Calabar, Nigeria. (pp 157)

Obadan, M. I. (1997). Analytical framework for poverty reduction: issues of economic guide versus other strategies: In annual conference of Nigerian Economic Society, Obaseki (ed). Nigerian Economic Society, Ibadan.

Okhira, O. A. \& Obadeyi, J. A. (2015). Poverty, an African epidemic: Empirical evidence of Nigeria. Developing Country Studies, 5(6), 2939

Omoniyi, V. A. (2013) Policy implementation and rural poverty reduction in Nigeria (an analysis of the National Poverty Eradication Programme (NAPEP) in Ado-odo Ota local government area, Ogun STATE) being a paper presented at $1 \mathrm{st}$ Annual International Interdisciplinary Conference, AIIC 2013, 24-26 April, Lagos State University,

Streeten, P. (1994). Human development: means and ends. American Economic Review, 84, 2, 232-237.

Toromade, S (2018) Benue crisis. What you need to know about Fulani herdsmen, Anti-open Grazing Law. Miyetti Allah. Freedom online Wilson-Osigwe, M. \& Oluwole, O. A. (2016) Implications of policy on extreme poverty and hunger in Nigeria from 1999 to 2015: prelude to post 2015 sustainable development programmes. Journal of Policy and Development Studies (JPDS) Vol. 10 (4)

World Bank Group (2019). Poverty. IBRD IDA IFC MIGA ICSID. https://www.worldbank.org/en/topic/poverty World Vision. (2019). Global poverty: facts, FAQS and how to help. Retrieve from http:www.worldvision.org/sponsorship-newsstories/global-poverty-facts. 